\title{
RESEARCH ON DECISION-MAKING SUPPORT OF CHINESE RURAL LAND TENURE INFORMATION SYSTEM
}

\author{
Jun $\operatorname{Tan}^{1}$, Hongyou $\mathrm{Su}^{1, *}$ \\ ${ }^{1}$ Dept. of Land \& Real Estate Management, Renmin University of China, Beijing \\ 100872, China \\ * Corresponding author, Address: Dept. of Land \& Real Estate Management, Renmin \\ University of China, Beijing100872, China. Tel: +86-10-62517572, Cell Phone: +86- \\ 13581684146,Email: hustshy@163.com
}

\begin{abstract}
Since 1949, the information of land tenure has a positive effect on defining the scope of collective land and state-owned land, implementing the system of cultivated land protection and land use control, designing general land use planning, etc. But as the economic and social development, the existing land tenure information is not appropriate anymore and results in many problems. The emphasis in the near future should be placed on establishing rural land tenure information system including cadastral management system, the uniform property registration system and cadastral management information system, defining the scope and content of various collective land ownership, securing peasants' land tenure rights, shortening the gap between urban and rural areas, all of which will guarantee the effective use of information of land tenure for the government's decision-making.
\end{abstract}

Keywords: Land Tenure Information, Cadastral Management, Tenure Rights Investigating, Land Registration

\section{INTRODUCTION}

The Chinese current land right system in force composes of land ownership, land use right and the other rights on land.

Until the establishment of Property Right Law last year, the long history of taking the registration of real estates as an administration measure had

Please use the following format when citing this chapter:

Tan, J. and Su, H., 2009, in IFIP International Federation for Information Processing, Volume 295, Computer and Computing Technologies in Agriculture II, Volume 3, eds. D. Li, Z. Chunjiang, (Boston: Springer), pp. 1957-1966. 
resulted in a mess in the regulations of real estate registration that can be seen in diversified independent civil laws or administrative regulations or judicial interpretations, e.g. Real Estate Administration Law, Mortgage Law, Land Administration Law, Agriculture Law, Contractual Management Law, Grassland Law, Forest Law, Land Registration Regulations, Forest and Forest Land Tenure Registration Administration Method, Sea Area Use Right Registration Method, etc.. And since a Real Estate Registration Law has never been existed so far in China, there is still no uniformed provision governing the registration of real estates. In addition, adversely affected by the impact of the society conversions, our legislation bodies have obviously placed too much importance on their administration while pay less attention to the function of guaranteeing transaction safety (Tan Jun,2005).

In late $1980 \mathrm{~s}$, the land and resources administration authorities have set out the registration of the use right of state-owned land, the ownership of rural collective's land, the use right of collective's land and other rights on land. With great efforts for decades, the registration for state-owned land in urban areas has been finished almost completely. Now, the registration of the ownership of rural collective's land has been progressing all over the country. However, the registration of the use right of collective's land has been carried out only in a small part of the vast rural areas (Evelyn Chia, 2006).

\section{CONSTRUCTION OF COLLECTIVE-OWNED LAND TENURE INFORMATION SYSTEM IS AN IMPORTANT FACTOR AFFECTING THE STABILITY OF RURAL AREAS}

According to analysis of Ministry of Land and Resources on letters of complaint from the people in recent years, the visits due to condemnation of rural collective-owned land, land compensation, and vague land ownership took up considerable proportion of the letters of complaints from the people.

\subsection{Upper rural collective organizations infringe the rights and interests of lower rural collective organizations.}

Major embodiments: The township (town) allots land of administrative villages at will or the administrative village freely allots the land of village teams; the township or administrative village freely allocates land compensation belonging to villages or teams. According to initial analysis of department for letters from and calls by the people of Ministry of Land and 
Resources, visits due to above disputes and cases of teams accusing villages and villages accusing townships have been growing in recent years.

\subsection{Land users owe land compensation for long.}

It occurs from time to time that land users owe land compensation. Certain chemical plant in Panjin City of Liaoning Province owed land compensation totaling 1,600,000 Yuan to certain villager team for 12 years, peasants of the team urged payment and appealed to higher authority several times in vain, and they even blocked the plant gate several times. Hubei Zhongxiang City Bureau of Public Security, Nianpanshan Water Resources Development Company, etc. owed land compensation totaling 3,000,000 Yuan to Gongbeiqiao Village successively since 1993, which seriously affected resettlement of peasants and economic development of the village, and caused great dissatisfaction of peasants (Wang Shuzhen,2004; Tan Jun,2005).

\subsection{Villages and teams in the part between urban and rural areas resisted land condemnation due to low condemnation price and risk of unemployment.}

Such problems become more striking in economically developed regions. For instance, there are nearly 200,000 peasants in Panyu City of Guangdong Province who have no land or lack land and are much annoyed against land condemnation. And land condemnation is rarely paid enough according to existing standard. For land condemnation by Linying County Development Zone of Henan Province, the price should be 20,000 25,000 Yuan per MU according to legal standard and yet the government fixes the price only at 3500 7000 Yuan per Mu. No. 201 National Road condemns 700Mu of cultivated land in Wanli Town, Dongsheng City, Yi League, Inner Mongolia, land compensation should be 4000 5000 Yuan per Mu according to existing laws, yet only 1500 Yuan is offered per $\mathrm{Mu}$, and so the peasants resist condemnation (Yang Sui,2005).

\subsection{Adjust land by taking advantage of second round of land contracting.}

Some localities freely break the boundary of villager teams to out-contract land during second round of land contracting, which leads to land disputes; some local villages and townships adjust some land for intensive management by taking advantage of second round of contracting, which leads to disputes; some localities out-contract, within the scope of the whole 
village, the land, which the village has been developing and running for dozens of years and which once belonged to villager teams, but the villager teams ask for return of the land ownership, which results in land dispute. These disputes exist to different degrees in all localities, and some of them affect spring farming and have to postpone second round of contracting after autumn (James Kai-sing Kung,2002).

Above disputes are striking problems in current development and stability of rural areas and more complicated, many of them are related to construction of collective-owned land title system. The reasons are exhibited in two aspects: First, collective-owned land has vague ownership and boundaries; second, the contents of ownership of collective-owned land in rural areas are unclear. If not handled properly, the disputes will affect the normal operation of local governments, demand much energy of all levels of cadres, and be unfavorable for protection of the rights and interests and stability of rural areas, unfavorable for arousing the enthusiasm of peasants to remain and input investment in cultivated land, and unfavorable for the planning, management, protection, and reasonable land use.

\section{CURRENT PROGRESS OF OWNERSHIP INFROMATION SYSTEM CONSTRUCTION OF COLLECTIVE-OWNED LAND IN RURAL AREAS OF CHINA}

Chinese government began to establish the rural land tenure information system by promoting ownership registration and certificate issue of collective-owned land in rural areas of China. The trial project of adjudication investigation of collective-owned land in rural areas of China started formally in 1999. By the end of 2005, Ministry of Land and Resources had set up trial places for rural collective-owned land adjudication investigation in 24 counties (cities) of 11 provinces in China. The special cost for investigation of land and resources totaling 7,300,000 Yuan is input in the trial places, all trial districts of the project have fund support, and the ratio of national financial cost over local match cost is about 1:4. Meanwhile, most districts have started such operation on the basis of self-trial successively.

According to comprehensive statistics of Ministry of Land and Resources on cadastral management, contrast to 2006, the initial use right registration and certificate granting of state-owned land increased 2,494,000 in the year of 2007, while the initial ownership registration and certificate granting of collective-owned land increased 75,000 and the initial use right registration and certificate granting of collective-owned land increased 3,510,000. China 
had accomplished 53\% ownership registration of collective-owned land and $73 \%$ use right registration of collective-owned construction land.

Ownership registration and certificate issue in China falls into three categories according to the degree of completion: 1) provinces (regions) of rapid progress, mainly include Shandong, Xinjiang, Heilongjiang, Fujian, Anhui, and Gansu, etc. In these regions, adjudication investigation and certificate issue of rural collective-owned land started early, and some of them are trial regions of the state. 2) Provinces (regions) of ordinary progress, mainly include Hebei, Henan, Guizhou, Jiangsu, Hainan, Hubei, Shanxi, etc. These regions started registration and certificate issue in 2000 2002, and the work went on smoothly since the government paid high attention and took effective measures. 3) Provinces (regions) of slow progress mainly include Sichuan, Guangdong, etc. Registration and certificate issue was restricted by all kinds of factors.

\section{ANALYSIS OF THE EFFECT OF OWNERSHIP REGISTRATION AND CERTIFICATE ISSUE OF COLLECTIVE-OWNED LAND IN RURAL AREAS OF CHINA}

\subsection{Strengthen land ownership construction to maintain the rights and interests of collective-owned and state- owned land.}

Land registration and issue of land ownership, use right, and other right certificate to land obliges is not only an administrative act but also a very solemn legal act. For a considerably long period to come, title construction and improvement of collective-owned land in rural areas of China will still be the most important problem among "three-agriculture" problems. Current adjudication survey, registration, and certificate issue of rural collectiveowned land makes the ownership of collective-owned land in counties (cities, districts), townships (towns), and villages more definite, and confirm them legally, which will play an active role in improving land ownership system, developing land use right and other right systems, establishing land title registration system, clarifying the legal effect of land registration, strengthening rural contract responsibility system, establishing the modern title system that renders clear ownership, definite rights and liabilities, strict protection, and smooth transfer, strengthening mediation and treatment of 
land disputes, and maintaining the rights and interests of collective-owned and state-owned land.

\subsection{Improve cultivated land protection mechanism and strictly implement cultivated land conservation system.}

It has been the goal of all levels of departments of land and resources to improve cropland protection mechanism, and implement most strict cropland conservation system. Title investigation, registration, and certificate issue of collective-owned land in rural areas reflect the quantity, type, distribution, and ownership of counties (cities, districts), townships (towns), and villages in data table and also put such information on geographical maps to provide scientific basis for achieving dynamic balance of cultivated land acreage, establishing long-term mechanism for protection of basic farmland, strengthening and improving cropland protection target responsibility system, cultivated land occupation and supplement responsibility system, and land price appraisal system, and lay sound foundation for implementing the most strict cropland conservation system, discovering problems in use and protection of cultivated land, and investigating and punishing illegal acts involving land.

\subsection{Enhance the technical level of land management.}

The major results of ownership investigation of rural collective-owned land and certificate issue may be used to update the land use database at county (city, area) level and establish rural cadastral database, which will greatly promote network management of land market information, cadastral information, land use information, and land market information, as well as standard management of rural cadastre. Not only speeds up information of land and resources and provides the service platform for sharing land information, but also promotes transfer of land management to modern method and creates favorable conditions for enhancing land management level and social services.

\subsection{Solve land ownership disputes to maintain social stability.}

The existence and occurrence of land ownership disputes seriously affect the normal production and life of people in the disputed areas, and bring about disastrous consequences to agriculture, forestry, and husbandry; in some districts, land ownership disputes lead to fight and personal casualty, 
affect national unity, and endanger social stability. In the process of ownership registration and certificate issue of rural collective-owned land, a large group of land ownership disputes are investigated and settled, which enhances social stability. Take Hainan Province for instance, since land ownership starts to be fixed, all levels of governments and relevant departments concentrate to solve a group of land disputes influential in the society, investigate and settle 2031 cases totaling $588,200 \mathrm{Mu}$ of land, and maintain social stability. Since the ownership of land starts to be fixed, the appeals and complaints of the masses have declined rapidly; the ratio in total cases declined from $64 \%$ in the first half of 2004 to below $40 \%$ at the end of 2004 , and the effect promoting social stability was gradually exhibited.

\section{EFFECTIVE APPROACH TO ESTABLISH LAND TENURE INFORMATION SYSTEM IN RURAL AREAS OF CHINA}

\section{$5.1 \quad$ Existing problems}

The land in rural areas of China has gone through several big adjustments since founding of People's Republic of China, vague ownership exists in large quantity of land between collectives, collective and the state, collective and military forces, enterprises, schools, etc., and most land ownership disputes have complicated reasons, involve broad aspects, last long period of time, and are much difficult for settlement. For 50 years, due to improper settlement of land ownership disputes by some local governments, new contradictions have appeared and influenced society's stability.

Determination of land ownership is governmental act, yet the infringement of peasants' land ownership is usually exhibited in governmental examination and approval of land use in violation of laws and regulations, and the protection of peasants' interest usually depends on the investigation and punishment of local government and land management departments over illegal act, so it is not practical to solve infringement of peasants' interests only through land registration. But we can start from enhancing the consciousness of local governments and land management departments to protect peasants' interests, and strengthening investigation and punishment of infringing peasants' interests in violation of laws and regulations (He Kangning, 2005).

Land registration should be a legal act and the oblige should make application actively. Current ownership registration of rural collectiveowned land is actually administrative work. Usually village cadres and 
peasant representatives believe that such work is arranged by the county government and land department. They do not recognize how much benefit the results of ownership registration can bring about to the peasants. Since the ownership subject of rural collective-owned land is not definite, the peasants pay more attention to the contracting right and use right of land.

Some leaders of local governments and land resources departments have not sufficient understanding of ownership registration and certificate issue of collective-owned land, and can not relate such work to solving threeagriculture problems, protecting the legal rights and interests of rural land, maintaining social stability in rural areas. They even believe falsely that to start ownership registration and certificate issue of collective-owned land, fix the ownership of collective-owned land, and clarify the rights of peasants over land will be unfavorable for local condemnation of collective-owned land (Loren Brandt et al.,2004).

At present, ownership registration and certificate issue of collectiveowned land mainly makes use of materials on current land use survey. Yet this information poorly reflects the practicality, and new maps are formulated slowly through numerous procedures and can not meet the actual need of adjudication survey. Such situation is fairly striking in economically backward regions, such as Inner Mongolia, Guangxi, Qinghai, etc.

\subsection{Solution channels}

First, unify regulations, clarify the scope and contents of all kinds of collective-owned land ownership, and solve all kinds of ownership disputes effectively.

Second, considering reduction of peasant burdens and maintenance of rural stability, in view of the welfare nature of ownership registration and certificate issue of collective-owned land, it is proposed to list the costs for such work into fiscal budget to be shared by all levels of finance or to allow such costs listed from paid use of land, the central authority offers certain sum, and the provinces, cities, and counties provides some amount to meet the costs.

Third, fully display the function of "Collective-owned Land Ownership Certificate" in using agricultural land for other purpose, examination and approval of built-up and associated land, and establishment of land development and reclamation arrangement, take "Collective-owned Land Ownership Certificate" as the key examination document in system and implement it strictly, Combine construction of land use database and land use updating survey, cadastral management etc. to undertake ownership registration and certificate issue of collective-owned land.

Forth, to avoid the problems due to data difference between the result of ownership registration and certificate issue of collective-owned land and the 
result of field survey for land condemnation effectively, town planning area and planning area of townships, farms, and towns having completed 1/500 cadastral survey, investigate the land ownership, register and issue certificate according to the survey results; town planning area and planning area of townships, farms, and towns having not completed 1/500 cadastral survey, and ownership of other rural collective-owned land within counties, only investigate land ownership, and both sides of ownership sign "Collectiveowned Land Ownership Investigation Table" for confirmation. Next, divide the results acquired through field survey into parcels for filing. "Collectiveowned Land Ownership Certificate" for the part of rural collective-owned land shall be registered and issued after completion of 1/500 town cadastral survey.

Fifth, considering China has vast rural areas and economic level varies a great deal with different regions, the localities may adopt different technical methods during investigation and certificate issue .In economically well-off regions, make use of orthographical image or aerial picture superimposed with current land use drawing to divide and determine land ownership boundary. In regions with ordinary economic conditions, make use of field investigation and plotting of current land use drawing to make supplement survey of changing land class and divide ownership boundary. In regions with poor economic conditions, if there is no dispute about ownership boundary, current land use drawing may be based to fix ownership boundary in reference to definite ground object (Tao Yinghu, 2005).

Sixth, ownership registration and certificate issue of collective-owned land is highly technical and of strong policy nature, and concerns land ownership survey, land ownership dispute mediation and treatment, cadastral mapping, land registration, cadastral information system construction, etc., so that the work staff should not only be familiar with laws, regulations, and polices on land management but also grasp technologies of cadastral management comprehensively. It is, therefore, necessary to strengthen training, stabilize and construct a highly qualified team, especially township land management team to meet the requirements of modern cadastral management.

\section{CONCLUSION}

The existing land tenure information system of Chinese rural area can't follow the economic and social developments and leads to many problems. To make use of information of land tenure for the government's decisionmaking, we should pay more attention on defining the scope and content of various collective land ownership, promoting the ownership registration and 
certificate issue, applying high technical investigating methods, securing peasants' land tenure rights and using all these measures to establish a new rural land tenure information system.

\section{ACKNOWLEDGEMENTS}

Some dates and conclusions come from the study on the law system and theoretic by Ministry of Justice L.R.C in year 2006: the land's property right security and the registration system (06SFB5027).

\section{REFERENCES}

Evelyn Chia. Institutions in Transition: Land Ownership, Property Rights and Social Conflict in China. The China Journal, 2006, 55(1):157-158

He Kangning. Explore the rural property right reformation. Theory and Contemporary, 2005(9):20-24(in Chinese)

James Kai-sing Kung. Choice of land tenure in China: The case of a county with quasi-private property rights. Economic Development and Cultural Change, 2002, Vol. 50, Iss. 4:793815

Li Yuan. Persist on system innovation and push the reformation of rural collective land used for building system. National Land \& Resources Information, 2003(6):34-37(in Chinese)

Loren Brandt, Scott Rozelle, Matthew A Turner. Local Government Behavior and Property Right Formation in Rural China. Journal of Institutional and Theoretical Economics, 2004, Vol. 160, Iss. 4:627

Tan Jun. Research of real property right registration system. Beijing: China Literary History Press, 2005

Tao Yinghu. Establish modern rural property right system adapted to market economy. Rural Economy, 2005(11):22-24

Wang Shuzhen. Rural property right system and protection of ploughed land. Theory Front, 2004(18):37-38(in Chinese)

Yang Sui. The basic character of rural property right system in China. Rural Economy, 2005(6):42-43 